\title{
к-Opioid Receptor Activation Modifies Dopamine Uptake in the Nucleus Accumbens and Opposes the Effects of Cocaine
}

\author{
Alexis C. Thompson, ${ }^{1}$ Agustin Zapata, ${ }^{1}$ Joseph B. Justice Jr, ${ }^{2}$ Roxanne A. Vaughan, ${ }^{3}$ Lawrence G. Sharpe, ${ }^{1}$ \\ and Toni S. Shippenberg ${ }^{1}$ \\ ${ }^{1}$ Behavioral Neuroscience Branch, National Institute on Drug Abuse, National Institutes of Health, Baltimore, Maryland \\ 21224, ${ }^{2}$ Department of Chemistry, Emory University, Atlanta, Georgia 30322, and ${ }^{3}$ Department of Biochemistry and \\ Molecular Biology, University of North Dakota, School of Medicine and Health Sciences, Grand Forks, North Dakota 58202
}

Coadministration of $\kappa$-opioid receptor agonists ( $\kappa$-agonists) with cocaine prevents alterations in dialysate dopamine (DA) concentration in the nucleus accumbens (Acb) that occur during abstinence from repeated cocaine treatment. Quantitative microdialysis was used to determine the mechanism producing these effects. Rats were injected with cocaine $(20 \mathrm{mg} / \mathrm{kg}$, i.p.), or saline, and the selective $\kappa$-agonist U-69593 (0.32 mg/kg, s.c.), or vehicle, once daily for $5 \mathrm{~d}$. Extracellular DA concentration $\left(D A_{\text {ext }}\right)$ and extraction fraction $\left(E_{\mathrm{d}}\right)$, an indirect measure of DA uptake, were determined $3 \mathrm{~d}$ later. Repeated cocaine treatment increased $E_{\mathrm{d}}$, whereas repeated $U-69593$ treatment decreased $E_{d}$, relative to controls. Coadministration of both drugs yielded intermediate $E_{\mathrm{d}}$ values not different from controls. In vitro DA uptake assays confirmed that repeated U-69593 treatment produces a doserelated, region-specific decrease in DA uptake and showed that acute U-69593 administration increases DA uptake in a nor- binaltorphimine reversible manner. Repeated U-69593 also led to a decrease in $\left[{ }^{125} \mathrm{I}\right] \mathrm{RTI}-55$ binding to the DA transporter (DAT), but did not decrease total DAT protein. These results demonstrate that $\kappa$-opioid receptor activation modulates DA uptake in the Acb in a manner opposite to that of cocaine: repeated U-69593 administration decreases the basal rate of DA uptake, and acute U-69593 administration transiently increases DA uptake. $\kappa$-agonist treatment also alters DAT function. The action of $\kappa$-agonists on DA uptake or DAT binding, or both, may be the mechanism(s) mediating the previously reported "cocaineantagonist" effect of $\kappa$-opioid receptor agonists.

Key words: к-opioid receptors; dopamine; dopamine uptake; cocaine; nucleus accumbens; striatum; quantitative microdialysis; rotating disk electrode voltammetry; autoradiography; Western blot; rats
Acute cocaine administration increases extracellular dopamine (DA) levels in the nucleus accumbens (Acb) by blocking the DA transporter and inhibiting DA clearance (Reith, 1988; Ritz et al., 1990). This action underlies the reinforcing effects of cocaine and may lead to the development of compulsive drug use (Wise and Bozarth, 1987; Kuhar et al., 1991). A marked enhancement of the psychomotor stimulant and rewarding effects of cocaine occurs after repeated cocaine administration (Lett, 1989; Stewart and Badiani, 1993; Shippenberg and Heidbreder, 1995; Schenk and Partridge, 1997). This phenomenon, referred to as behavioral sensitization, persists for weeks after cessation of cocaine use and is implicated in the reinstatement of cocaine-seeking behavior (Kalivas and Duffy, 1993a; Henry and White, 1995; Shippenberg and Heidbreder, 1995). Behavioral sensitization is associated with an increase in firing rate of mesolimbic DA neurons (Henry et al., 1989), an elevation of basal DA dialysate levels (Kalivas and Duffy, 1993a,b; Heidbreder et al., 1996), and an increase in the basal rate of DA uptake (Ng et al., 1991; Parsons et al., 1991; Meiergerd et al., 1994; Jones et al., 1995). These adaptations in presynaptic DA activity are thought to contribute to the development and longterm expression of behavioral sensitization (Kalivas and Stewart, 1991).

Coadministration of $\kappa$-opioid receptor agonists ( $\kappa$-agonists) with cocaine prevents cocaine-induced behavioral sensitization (Heidbreder et al., 1993; Shippenberg et al., 1996) and the increase in basal DA dialysate levels that occurs during cocaine abstinence

\footnotetext{
Received May 26, 2000; revised Oct. 2, 2000; accepted Oct. 9, 2000.

Correspondence should be addressed to Dr. Alexis C. Thompson, Behavioral Neuroscience Program, Department of Psychology, Park Hall, State University of New York at Buffalo, Buffalo, NY 14260. E-mail: act2@buffalo.edu.

This research was supported by Intramural Research Funds from the National Institute on Drug Research to T.S.S., and National Institutes of Health Grants DA10896 and DA11176 to J.B.J. Many thanks to William Rea and Heather Holden for their excellent technical assistance.

Copyright (C) 2000 Society for Neuroscience $0270-6474 / 00 / 209333-08 \$ 15.00 / 0$
}

(Heidbreder and Shippenberg, 1994). Acute administration of $\kappa$-agonists decreases DA levels in the Acb (DiChiara and Imperato, 1988; Donzanti et al., 1992; Maisonneuve et al., 1994), and some have hypothesized that this action of $\kappa$-agonists, which functionally opposes the acute effect of cocaine, underlies the cocaineantagonistic effect of repeated $\kappa$-agonists.

Changes in dialysate concentration of a neurotransmitter are traditionally attributed to changes in extracellular concentration that are secondary to changes in release. However, recovery of monoamines by the dialysis probe has been shown to vary directly with the rate of monoamine clearance: increases in DA uptake increase DA recovery, and decreases in DA uptake reduce DA recovery (Bungay et al., 1990; Smith and Justice, 1994; Cosford et al., 1996). Therefore, changes in dialysate monoamine concentration may be caused by changes in either release or clearance, or both. The present study was conducted to test the hypothesis that $\kappa$-agonists prevent cocaine-induced changes in DA uptake. The no net flux microdialysis method (Lönnroth et al., 1987) was used to characterize basal DA dynamics in rats after repeated administration of cocaine, the selective $\kappa$-agonist U-69593 (Lahti et al., 1985), or cocaine in combination with U-69593. This method provides an unbiased estimate of extracellular DA concentration and an indirect measure of DA uptake (Bungay et al., 1990; Justice, 1993). Rotating disk electrode voltammetry, autoradiography, and immunoblotting were then used, respectively, to directly assess the influence of U-69593, in the presence or absence of cocaine, on the rate of DA uptake, binding to the DA transporter (DAT), and total DAT protein in Acb and dorsal striatum (STR).

\section{MATERIALS AND METHODS}

\section{Subjects}

Subjects were male Sprague Dawley albino rats purchased from Charles River Farms (Wilmington, MA) or Harlan Farms (Prattsville, AL) 2-6 weeks before any manipulation. Rats were maintained in facilities at the National Institute on Drug Abuse (NIDA) (Baltimore, MD; Experiments 
1, 3, 4, and 7) or in facilities at Emory University (Atlanta, GA; Experiments 2, 5, and 6). Experiments were conducted in accordance with the guidelines established by the Institutional Animal Care and Use Committee (IACUC) of the Intramural Research Program of the NIDA, National Institutes of Health, and the Emory University IACUC. The facilities at Emory University were fully accredited by the American Association for the Accreditation of Laboratory Animal Care, and the facilities at NIDA were maintained according to the Guide for Care and Use of Laboratory Animals of the Institute of Laboratory Animals Resources, National Research Council, Department of Health, Education and Welfare, Publication (National Institutes of Health 85-23, revised 1985).

Rats were housed in a colony room in groups of two, three, or five (except as noted in Experiment 1), where they were maintained under a constant temperature $\left(25^{\circ} \mathrm{C}\right)$ and a $12 \mathrm{hr}$ light/dark cycle (lights on at 6 A.M., Eastern Standard Time). Food and water were available ad libitum.

\section{Experiment 1: Influence of repeated U-69593 and cocaine treatment on $\mathrm{DA}_{\text {ext }}$ and $\mathrm{E}_{d}$ in the Acb}

Procedure. Rats $(n=60,275-450 \mathrm{gm})$ were implanted unilaterally with a permanent indwelling guide cannula (CMA10, CMA, Inc., Nagog, MA) aimed at the Acb [anteroposterior, $+1.4 \mathrm{~mm}$; mediolateral, $-1.4 \mathrm{~mm}$; dorsoventral, $-5.7 \mathrm{~mm}$, from bregma, as illustrated in Paxinos and Watson (1986)] under sodium pentobarbital $(60 \mathrm{mg} / \mathrm{kg}$, i.p.) or Equithesin (3 $\mathrm{ml} / \mathrm{kg}$, i.p.; $9.7 \mathrm{gm}$ sodium pentobarbital, $42.5 \mathrm{gm}$ chloral hydrate, and 21.3 gm $\mathrm{MgSO}_{4}$ dissolved in 11 of $11 \%$ ethanol and $42 \%$ propylene glycol, $\mathrm{v} / \mathrm{v}$ ) anesthesia. After surgery, rats were housed individually in the colony room and allowed to recover for 1 week. After the recovery period, rats were assigned to one of four treatment groups: U-69593 + cocaine, vehicle + cocaine, U-69593 + saline, or vehicle + saline. U-69593 (0.32 mg/kg, s.c.), or its vehicle (20\% propylene glycol, $1 \mathrm{ml} / \mathrm{kg}$, s.c.), was injected $20 \mathrm{~min}$ before the cocaine $(20 \mathrm{mg} / \mathrm{kg}$, i.p.), or its vehicle (saline, $1 \mathrm{ml} / \mathrm{kg}$, i.p.), once per day for $5 \mathrm{~d}$. All drugs were administered in the home cage. Microdialysis was conducted $3 \mathrm{~d}$ after the last drug treatment.

Microdialysis. Approximately $10 \mathrm{hr}$ before dialysis sample collection began, rats were placed in Plexiglas microdialysis chambers $(40 \times 40 \times 35$ $\mathrm{cm}$ ) in a separate room where the temperature, light, and feeding conditions were maintained as described previously. A microdialysis probe (CMA10, CMA, Inc.) was inserted through the guide cannula and extended $2 \mathrm{~mm}$ from the tip of the cannula into the Acb. The inflow line to the probe was connected to a microinfusion pump (Harvard 22; Harvard Apparatus, South Natick, MA) via a liquid swivel (quartz-lined) and protected by a spring tether. The tether was attached at one end to the liquid swivel and at the other end to a screw embedded in the cranial cement stage on the rat's head. The swivel spring assembly (Instech Laboratories, Plymouth Meeting, PA) was hung from the top of the cage by a balance arm (Instech Laboratories) to allow free movement of the rat in the cage. The outflow tubing followed the same path as the inflow tubing, ending at the swivel inside a microcentrifuge tube. Artificial CSF (aCSF) containing (in mM): $145 \mathrm{NaCl}, 2.8 \mathrm{KCl}, 1.2 \mathrm{CaCl}_{2}, 1.2 \mathrm{MgCl}_{2}, 5.4$ $\mathrm{D}$-glucose, and 0.25 ascorbic acid, $\mathrm{pH} 7.2-7.4$, was perfused through the microdialysis probe at a rate of $1 \mu \mathrm{l} / \mathrm{min}$ for an equilibration period of $8 \mathrm{hr}$. The flow rate was increased to $2.2 \mu \mathrm{l} / \mathrm{min}, 2 \mathrm{hr}$ before the first sample collection, and remained at this rate for the duration of the experiment.

Twenty minute samples were collected over a $4 \mathrm{hr}$ period using the no net flux method of microdialysis as described by Justice (1993). Samples were immediately frozen on dry ice for later quantification of the dopamine content by HPLC and electrochemical detection. All microdialysis samples were collected between 8 A.M. and 1 P.M.

No net flux procedures. Four different concentrations of DA in aCSF $(0$, 5,20 , and $40 \mathrm{nM} D A_{\text {in }}$ ) were perfused in random order through the microdialysis probe. Each concentration was perfused for $1 \mathrm{hr}$. No sample was collected during the first $20 \mathrm{~min}$ of perfusion, allowing for a period of equilibration. Thereafter, two $20 \mathrm{~min}$ samples were collected at each DA concentration. Pilot studies were conducted to determine that a $20 \mathrm{~min}$ equilibration time was sufficient for each $\mathrm{DA}_{\text {in }}$ and this was confirmed during the experiment by agreement between duplicate samples at each perfused $D A_{\text {in }}$

Histology. At the end of the experiment, rats were decapitated, and their brains were removed and frozen for later histological examination. The placement of the microdialysis probe was determined in $25 \mu \mathrm{m}$ coronal sections taken from frozen unfixed brains using a cryostat (Hacker Instrument, Fairfield, NJ). Data from rats whose placement fell outside the Acb were excluded from the study $(n=3)$.

Data analysis. The concentration of dopamine in each sample was determined by HPLC and electrochemical detection. Aliquots $(20 \mu \mathrm{l})$ of each dialysate sample were injected onto an HPLC column $(100 \times 3.2 \mathrm{~mm}$, inner diameter, C-18, $3 \mu \mathrm{m}$ particulate silica gel; BAS-Phase II; Bioanalytical Systems, West Lafayette, IN). The mobile phase consisted of $0.15 \mathrm{M}$ $\mathrm{NaH}_{2} \mathrm{PO}_{4}, 1.0 \mathrm{~mm}$ ethylenediamine-tetra-acetate, $1.6 \mathrm{~mm}$ sodium octyl sulfate, $13 \%$ methanol $(\mathrm{v} / \mathrm{v})$, at an apparent $\mathrm{pH}$ of 5.0 . Mobile phase was perfused through the column at a rate of $1 \mathrm{ml} / \mathrm{min}$ using a BAS PM- 80 pump. The elution time for DA under these conditions was 3-4 min. Electrochemical detection was accomplished using a BAS LC-4C amperometric detector. The applied potential was $+0.700 \mathrm{~V}$ versus $\mathrm{Ag} / \mathrm{AgCl}$. Samples were quantified by comparison with an external standard curve constructed from $40 \mu \mathrm{l}$ aliquots of DA solutions $(0-100 \mathrm{~nm}$ in aCSF) prepared fresh each day and treated in a manner identical to the microdialysis samples. Sensitivity for DA was $>1 \mathrm{nM}$.

The dialysate DA data from each rat $\left(D A_{\text {out }}\right)$ were used to construct a linear equation that described the change in the perfusate DA concentration $\left(D A_{\text {in }}\right)$ that resulted from dialysis: the net change in DA $\left(D A_{\text {in }}-\right.$ $\left.D A_{\text {out }}\right)$ was regressed against $D A_{\text {in }}$ to derive this linear equation. The dependent variables were extracellular DA concentration $\left(D A_{\text {ext }}\right)$, an estimate of extracellular DA concentration that is independent of relative recovery of DA, and extraction fraction $\left(E_{\mathrm{d}}\right)$, the rate of DA delivery from the probe to the tissue and an indirect measurement of the rate of DA uptake. The dependent variables were determined from the linear regression equation as described by Parsons et al. (1991). In a scatter plot of $D A_{\text {in }}$ by $D A_{\text {in }}-D A_{\text {out }}$ extracellular DA concentration $\left(D A_{\text {ext }}\right)$ is the value of $D A_{\text {in }}$ at which $D A_{\text {in }}-D A_{\text {out }}$ equals zero and $E_{\mathrm{d}}$ is the slope of the linear regression.

A two-way ANOVA [ $\kappa$-agonist $(\mathrm{U}-69593$ or vehicle) $\times$ cocaine (cocaine or saline)] was used to assess group differences for each dependent measure, $D A_{\text {ext }}$ and $E_{\mathrm{d}}$.

\section{Experiment 2: Influence of repeated U-69593 treatment on DA uptake in Acb and STR tissue}

Procedure. Rats $(n=14,250-350 \mathrm{gm})$ were treated once per day for $5 \mathrm{~d}$ with U-69593 $(0.32 \mathrm{mg} / \mathrm{kg}$, s.c. $)$ or vehicle. Three days after the last treatment, rats were decapitated, the brains were rapidly removed, and the Acb and STR were rapidly dissected to analyze the rate of DA uptake by rotating disk electrode (RDE) voltammetry. Two additional experiments were conducted in follow-up: additional groups of rats were treated with either varying doses of U-69593 $(0.03,0.1$, or $0.32 \mathrm{mg} / \mathrm{kg}$, s.c. $)$ or vehicle once per day for $5 \mathrm{~d}$, and DA uptake was assessed by RDE voltammetry $3 \mathrm{~d}$ later $(n=28,250-350 \mathrm{gm})$, and additional groups of rats were treated with one dose of U-69593 (0.32 mg/kg, s.c.) or vehicle once per day for $5 \mathrm{~d}$, and changes in the kinetics of DA uptake were assessed using RDE voltammetry 3 d later $(n=22,250-300 \mathrm{gm})$. In the latter experiment, procedures described by Povlock and Schenk (1997) were used to construct a Michaelis-Menton expression from which the $V_{\max }$ and $K_{\mathrm{m}}$ were determined.

Dissections. A $4 \mathrm{~mm}$ section from the anterior portion of the brain was removed (beginning $3 \mathrm{~mm}$ posterior to the anterior pole) with the aid of a metal brain matrix. A $2 \mathrm{~mm}$ coronal section was placed on an ice-cold plate, and the Acb was removed bilaterally by dissecting a $3 \times 2 \mathrm{~mm}$ oval section surrounding the anterior commissure, which typically yielded $10-15 \mathrm{mg}$ of tissue. The STR was removed by cutting out a $4 \mathrm{~mm}$ round section from the center of the left or right STR. Only a single STR was used (left and right sampled alternately).

DA uptake assay. After dissection, the Acb and STR tissues were quickly weighed, placed into $1.5 \mathrm{ml}$ microcentrifuge tubes, and submerged in 500 $\mu \mathrm{l}$ of $4^{\circ} \mathrm{C}$ physiological saline buffer until the start of assay $(5 \mathrm{~min}$ and 25 min later for the Acb and STR, respectively). The buffer consisted of (in $\mathrm{mm}$ ): $124 \mathrm{NaCl}, 3 \mathrm{KCl}, 1.24 \mathrm{KH}_{2} \mathrm{PO}_{4}, 1.30 \mathrm{MgSO}_{4}, 2.50 \mathrm{CaCl}_{2}, 26.0$ $\mathrm{NaHCO}_{3}$, and 10 D-glucose, $\mathrm{pH} 7.4$, and gassed with a $95 \% \mathrm{O}_{2} / 5 \% \mathrm{CO}_{2}$ mix. The tissue was washed twice by removing and then replacing $400 \mu \mathrm{l}$ of the ice-cold buffer. Next, $400 \mu \mathrm{l}$ of the cold buffer was replaced with room temperature buffer, and the tissue solution was increased to $37^{\circ} \mathrm{C}$ over $5 \mathrm{~min}$. The tissue was carefully removed from the microcentrifuge tube, placed on a glass dish, and minced with two scalpel blades. The minced tissue was placed into an electrochemical cell with $300 \mu \mathrm{l}$ of $37^{\circ} \mathrm{C}$ buffer. During the assay, the tissue was maintained at $37^{\circ} \mathrm{C}$, subjected to a constant stream of $95 \% \mathrm{O}_{2} / 5 \% \mathrm{CO}_{2}$ gas directed over the top of the electrochemical cell, and stirred at $4000 \mathrm{rpm}$.

Voltammetric measurements were made before ( $\sim 5 \mathrm{~min})$ and for $1 \mathrm{~min}$ after a $6 \mu \mathrm{l}$ addition of DA (100 $\mu \mathrm{M}$ in buffer). The electrochemical cell and the supporting RDE voltammetry system were described by Burnette et al. (1996) and Welch and Justice (1996). The applied potential was $+450 \mathrm{mV}$ versus $\mathrm{Ag} / \mathrm{AgCl}$. Data acquisition and analysis were performed using Origin data acquisition software (MicroCal, Northampton, MA) on a 486 PC.

Data analysis. The velocity of DA uptake into Acb and STR tissue was calculated from the initial rate of decay in DA concentration that followed the addition of DA to the electrochemical cell, as in Welch and Justice (1996). The $6 \mu$ l addition of DA increased the DA concentration in the minced tissue solution to $2 \mu \mathrm{M}$. The increase in DA concentration was detected as an increase in the electrochemical oxidative current that peaked rapidly and then decayed. The initial rate of decay in current has been shown to result solely from the uptake of DA into the tissue through catecholamine transporters (Schenk et al., 1990; Povlock and Schenk, 1997). Calculation of the initial velocity of DA uptake was made on $10 \mathrm{sec}$ of the DA decay data between 1 and $11 \mathrm{sec}$ after the addition of DA to the electrochemical cell. Data were normalized to the weight of the tissue used in each experiment and expressed as the initial velocity of DA uptake in picomoles per second per gram of wet tissue weight.

Kinetic parameters, $V_{\max }$ and $K_{\mathrm{m}}$, were determined by following the procedure described in Povlock and Schenk (1997). Acb tissue suspensions were exposed to increasing concentrations of DA $(0.25,0.5,1,2$, and $3 \mu \mathrm{M}$ DA final concentration), and after each DA concentration, the initial velocity was determined as described above. Each addition of DA took place when the DA signal from the previous addition had returned to the original baseline level. This experimental design has been shown to produce conditions approaching the apparent low-to-infinite trans experiment 
as characterized by Povlock and Schenk (1997). Values of $K_{\mathrm{m}}$ and $V_{\mathrm{ma}}$ were estimated by fitting experimentally observed values of the initial velocity by each DA concentration to the Michaelis-Menten expression using commercially available nonlinear curve fitting software (Prism, San Diego, CA).

One-way ANOVA was used to compare the dependent measure (picomoles per second per gram of tissue weight or kinetic parameter) among treatment groups. When appropriate, specific group differences were identified in post hoc analyses using a Newman-Keuls pairwise comparison of the group means test at $p<0.05$.

\section{Experiment 3: Influence of repeated U-69593 and cocaine treatment on $\left[{ }^{125} I\right] R T I-55$ binding in Acb and STR}

Procedure. Rats $(n=16,250-350 \mathrm{gm})$ were treated once per day for $5 \mathrm{~d}$ with U-69593 $(0.32 \mathrm{~m} / \mathrm{kg}$, s.c. $)$ or vehicle, and cocaine $(20 \mathrm{mg} / \mathrm{kg}$, i.p. $)$ or vehicle. Three days after the last treatment, rats were killed by decapitation, and the brains were rapidly frozen in isopentane and stored at $-80^{\circ} \mathrm{C}$ until sectioned.

Autoradiography. Frozen coronal sections $(20 \mu \mathrm{m})$, were cut and thawmounted onto chrome alum/gelatin-coated microscope slides, dried, and stored at $-80^{\circ} \mathrm{C}$ until processed for autoradiography. Two coronal sections within the caudoputamen region were mounted on each slide such that two slides (four consecutive sections) per animal were prepared for labeling with [ ${ }^{125}$ I]RTI-55, the ligand used to selectively label the DATs.

The brain sections were thawed to room temperature and preincubated for $30 \mathrm{~min}$ in $50 \mathrm{~mm}$ sodium phosphate buffer $\left(\mathrm{NaH}_{2} \mathrm{PO}_{4}, \mathrm{Na}_{2} \mathrm{HPO}_{4}, \mathrm{pH}\right.$ 7.4) containing $10 \mathrm{~mm} \mathrm{NaCl}$ and $0.1 \%$ bovine serum albumin (BSA). The slides were then incubated at room temperature for $4 \mathrm{hr}$ in the above buffer containing $1 \times$ protease inhibitor mixture $\left(1 \times\right.$ PIC) and $10 \mathrm{~nm}\left[{ }^{125} \mathrm{I}\right] \mathrm{RTI}-$ 55 (DuPont, NEN, specific activity $2200 \mathrm{Ci} / \mathrm{mmol}$ ). Sections used to assess total binding for DAT were incubated in the same buffer medium with the addition of unlabeled citalopram $(50 \mathrm{~nm})$ to block binding to the serotonin transporter. Nonspecific binding was assessed with the addition of unlabeled $10 \mu \mathrm{M}$ indatraline. After incubation the slides were washed for two 5 min periods in cold $\left(4^{\circ} \mathrm{C}\right)$ sodium phosphate buffer $(50 \mathrm{~mm}$, containing 10 $\mathrm{mm} \mathrm{NaCl}$ and $0.1 \% \mathrm{BSA}$ ), dipped in cold deionized water, and desiccated until completely dried $(\sim 1 \mathrm{hr})$.

Labeled slides and microscale standards for both radioligands were apposed to Hyperfilm- ${ }^{3} \mathrm{H}$ (both from Amersham, Arlington Heights, IL), and after $8 \mathrm{~d}$ of exposure at room temperature, the films were developed using commercially available $\mathrm{x}$-ray developers and fixers.

Data analysis. A Macintosh Apple Power G3 computer and a scanner (Powerlook 3000 with UMAX software) were used to digitize the brain sections on film. The NIH Image 1.62 program (developed at the National Institutes of Health and available on the Internet at http://rsb.info.nih.gov/ nih-image/) was used to construct the standard curves and to quantify relative optical densities of brain regions. The Rodbard curve, $y=c^{*}[(a-$ $x) /(x-d)] \wedge(1 / b)$, was used to quantify all brain regions because it was the curve of best fit. The optical densities from four coronal sections (specific binding) were averaged for each sampled region per animal. The averaged values were converted to femtomoles of radioligand bound per milligram of tissue equivalent (Kuhar and Unnerstall, 1990). Two sections per animal were used to average nonspecific binding, which was $<5 \%$ of total binding.

Group differences in binding (femtomoles per milligram of tissue) in $\mathrm{Acb}_{\text {shell }}, \mathrm{Acb}_{\text {core }}$, or dorsal STR were assessed statistically by two-way ANOVA [ $\kappa$-agonist $(\mathrm{U}-69593$ or vehicle $) \times$ cocaine $($ cocaine or saline $)]$ followed by simple effect probes.

\section{Experiment 4: Influence of repeated U-69593 and cocaine treatment on total DAT protein in Acb and STR}

Procedure. Rats ( $n=12,350-420 \mathrm{gm})$ were treated with U-69593 (0.32 $\mathrm{mg} / \mathrm{kg}$, s.c. $)$ or vehicle once per day for $5 \mathrm{~d}$ or, in a second study $(n=18$, $300-400 \mathrm{gm})$, treated with cocaine $(20 \mathrm{mg} / \mathrm{kg}$, i.p.), saline, or U-69593 + cocaine once per day for $5 \mathrm{~d}$. Three days later, rats were decapitated, and the Acb and STR were rapidly dissected as described in Experiment 2. The tissue was frozen for later determination of DAT concentration by immunoblot analysis. Western blotting was performed twice using tissue from three control rats and three rats from each treatment group each time, with each tissue sample analyzed in triplicate.

Western blot assay of DAT protein content. Immunoblots of DAT were obtained as described previously (Vaughan et al., 1993) using antiserum 15, generated against rDAT amino acids 6-30 (Vaughan and Kuhar, 1996). Tissue $(10-40 \mathrm{mg})$ from the Acb or STR was homogenized, membranes were solubilized in SDS-polyacrylamide gel sample buffer, and 50-100 $\mu \mathrm{g}$ protein was electrophoresed on 9\% SDS polyacrylamide gels. After transfer to $0.45 \mu \mathrm{M}$ nitrocellulose membranes (Schleicher and Schuell, Keene, $\mathrm{NH}$ ) and blocking, the membranes were probed for $1 \mathrm{hr}$ with antiserum 15 diluted $1: 100$. Antibody binding was detected with $\left.{ }^{125} \mathrm{I}\right]$ protein A $(0.8$ $\mu \mathrm{Ci} / \mathrm{ml}$; New England Nuclear, Boston, MA) followed by autoradiography with Kodak Biomax film at $-70^{\circ} \mathrm{C}$ for $12-36 \mathrm{hr}$, or by computer analysis with a Molecular Dynamics phosphorimager (Sunnyvale, CA). Standard curves performed in parallel and generated by tissue dilution showed excellent linearity of response and clearly quantifiable differences to $10 \%$ increments in sample amounts (data not shown) (Letchworth et al., 1999)

Data analysis. Data from the two replications were combined, yielding six rats/group, and then expressed as percentage of the average control values for comparison in each brain region. Group differences were assessed statistically by one-way ANOVA followed by a Newman-Keuls pairwise comparison of the group means test at $p<0.05$.

\section{Experiments 5 and 6: Influence of acute U-69593 on DA uptake in Acb tissue}

Procedure. The rate of DA uptake in the Acb after a single injection of U-69593 was assessed in vitro by RDE voltammetry using the same procedures described in Experiment 2. In Experiment 4 (time course), rats (250-350 gm, $n=26)$ were injected with U-69593 $(0.32 \mathrm{mg} / \mathrm{kg}$, s.c.) or its vehicle, and the rate of DA uptake was determined 1, 2, or $4 \mathrm{hr}$ later. In Experiment 5 (dose-response), rats $(250-350 \mathrm{gm}, n=31$ ) were treated with U-69593 $(0.03,0.10$, or $0.32 \mathrm{mg} / \mathrm{kg}$, s.c. $)$ or its vehicle, and the rate of DA uptake was determined $2 \mathrm{hr}$ later.

Data analysis. The initial rate of DA uptake was calculated as described in Experiment 2, and group differences by time or dose were assessed statistically by one-way ANOVA followed by a Newman-Keuls pairwise comparison of the group means test at $p<0.05$.

\section{Experiment 7: Influence of $\kappa$-opioid receptor blockade on the acute U-69593-induced increase in DA uptake in the Acb}

Procedure. Rats $(n=23,350-450 \mathrm{gm})$ were treated with a single injection of nor-binaltorphimine (nBNI) $(10 \mathrm{mg} / \mathrm{kg}$, s.c.) or vehicle $(1 \mathrm{ml} / \mathrm{mg}$ sterile water), 24-48 hr before treatment with U-69593 $(0.32 \mathrm{mg} / \mathrm{kg}$, s.c. $)$ or its vehicle. Rats were decapitated $2 \mathrm{hr}$ after the U-69593 treatment, and the Acb was removed for analysis of DA uptake by RDE voltammetry. The dose and treatment interval for nBNI was previously shown to result in the selective and long-lasting blockade of $\kappa$-opioid receptors (Horan et al., 1992; Spanagel et al., 1994).

Data analysis. The initial rate of DA uptake was calculated as described in Experiment 2 and group differences were assessed statistically by two-way ANOVA [ $\kappa$-antagonist $(\mathrm{nBNI}$ or vehicle) $\times \kappa$-agonist $(\mathrm{U}-69593$ or vehicle)] followed by simple effect probes.

\section{RESULTS}

\section{Effect of repeated U-69593 + cocaine treatment on $D A_{\text {ext }}$ and $E_{\mathrm{d}}$}

Histological analysis confirmed placement of the microdialysis probe within the Acb in $93 \%$ of the subjects. In these rats $(n=47)$, the active length of the probe was observed to lie medially in the anterior-posterior extent of the Acb and to traverse the dorsalventral length of the Acb medial to the anterior commissure (Fig. 1). No systematic group differences in placement were observed.

The no net flux microdialysis method was used to study changes in presynaptic DA dynamics in vivo. In contrast to conventional methods, this method provides an estimate of extracellular analyte concentration and in vivo extraction fraction (Lönnroth et al., 1987; Lönnroth et al., 1989). Extraction fraction, or $E_{\mathrm{d}}$, is a measure of the ability of the surrounding tissue to accept DA from the probe, and theoretical consideration of the dialysis process in neural tissue suggests an association between $E_{\mathrm{d}}$ and changes in DA clearance (Bungay et al., 1990). This relationship has received support from empirical observations in which DA uptake, but not release or metabolism, modifies DA $E_{\mathrm{d}}$ (Justice, 1993; Smith and Justice, 1994). Increasing DA uptake facilitates diffusion of DA from the probe into tissue and increases $E_{\mathrm{d}}$, whereas decreasing DA uptake reduces diffusion of DA into the tissue and decreases $E_{\mathrm{d}}$.

Figure 2 depicts the no net flux plot of the mean ( \pm SEM) change in perfusate DA concentration $\left(D A_{\text {in }}-D A_{\text {out }}\right)$ at each $D A_{\text {in }}$ and the average linear regression for each experimental group assessed in this experiment. Mean $( \pm \mathrm{SEM})$ basal $D A_{\text {ext }}$ and $E_{\mathrm{d}}$ are reported in Table 1. $D A_{\text {ext }}$ varied from $9.9 \pm 2.5 \mathrm{~nm}$ (U-69593 + cocaine) to $13.3 \pm 2.1 \mathrm{~nm}$ (U-69593 + saline), but did not differ significantly among treatment groups (interaction, $F_{(1,43)}<1$, U-69593 treatment main effect, $F_{(1,43)}<1$; cocaine treatment main effect, $F_{(1,43)}$ $<1)$. In contrast, main effects of cocaine treatment $\left(F_{(1,43)}=4.8\right.$, $p=0.03)$ and U-69593 treatment $\left(F_{(1,43)}=10.1, p=0.003\right)$ were significant for $E_{\mathrm{d}}$. After cocaine treatment, $E_{\mathrm{d}}$ was significantly increased relative to control. In contrast, after U-69593 treatment, $E_{\mathrm{d}}$ was significantly decreased relative to control. The interaction 


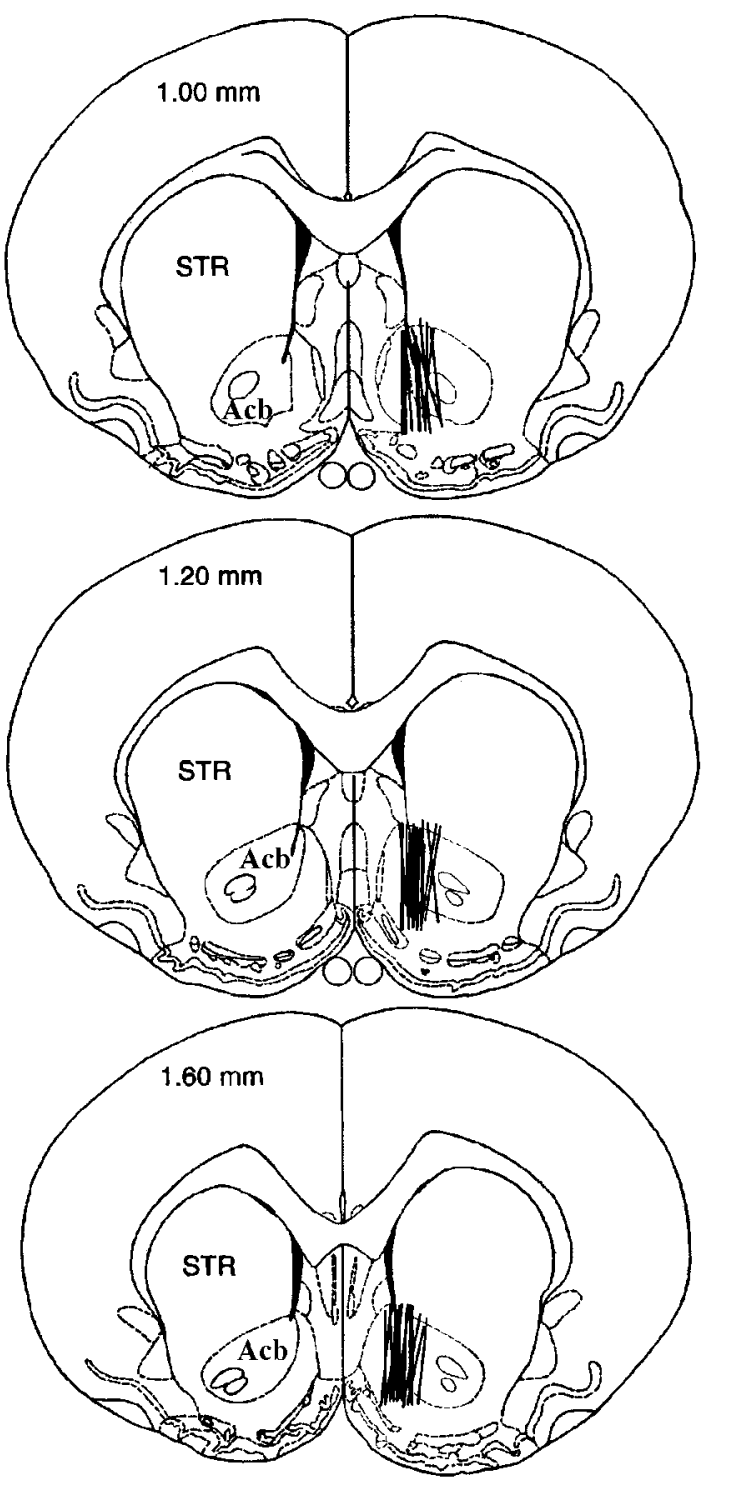

Figure 1. Illustration of microdialysis probe placement $(\mid)$ in the Acb (Experiment 1). Diagrams were adapted from Paxinos and Watson (1986) and are labeled in millimeters rostral to bregma. $A c b$, Nucleus accumbens; STR, dorsal striatum.

between U-69593 and cocaine was not significant $\left(F_{(1,43)}<1\right) . E_{\mathrm{d}}$ values in rats that had received U-69593 with cocaine (U-69593 + cocaine, $0.18 \pm 0.03$ ) were not different from controls (vehicle + saline, $0.22 \pm 0.03)$.

\section{Effect of repeated U-69593 treatment on DA uptake in Acb and STR}

RDE voltammetry was used to directly measure the effect of U-69593 treatment on the rate of DA uptake in Acb. As predicted from the microdialysis experiment, the rate of DA uptake in the Acb was significantly reduced, relative to controls, in rats that had received the $5 \mathrm{~d}$ U-69593 treatment regimen (Fig. $3 a)\left(F_{(1,10)}=6.8\right.$; $p=0.03)$. The effect was dose-related (Fig. $3 c)\left(F_{(3,23)} \stackrel{1}{=} 3.2 ; p=\right.$ 0.04 ) and region specific, because no decrease in the rate of DA uptake was observed in STR tissue from these same rats (Fig. $3 b$ ) $\left(F_{(1,12)}=3.1 ; p=0.11\right)$ regardless of dose (Fig. $\left.3 d\right)\left(F_{(2,24)}<1\right)$.

The observed changes in the initial velocity of DA clearance after the U-69593 treatment were associated with significant increases in both $K_{\mathrm{m}}\left(F_{(1,20)}=4.84, p<0.04\right)$ and $V_{\max }\left(F_{(1,20)}=\right.$ $4.83, p<0.04)$ in the Acb (Table 2).

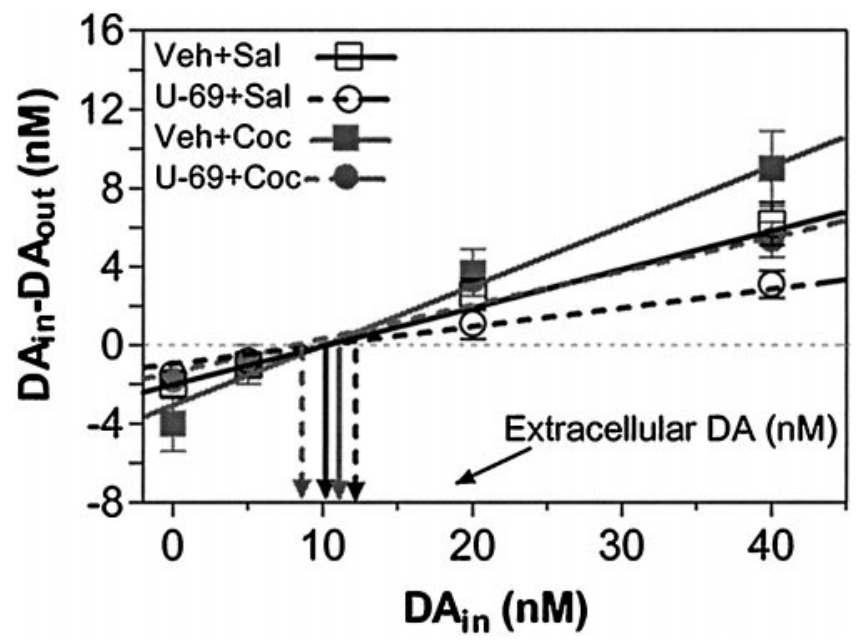

Figure 2. No net flux plot of dialysate DA data obtained from rats treated repeatedly with the $\kappa$-agonist U-69593 (0.32 mg/kg, s.c.) and/or cocaine (20 $\mathrm{mg} / \mathrm{kg}$, i.p.). Data were collected under steady-state conditions $3 \mathrm{~d}$ after a $5 \mathrm{~d}$ repeated drug treatment regimen (once per day). The no net flux plot shows the mean $\pm \mathrm{SEM}$ gain or loss of DA $\left(D A_{\text {in }}-D A_{\text {out }}\right)$ by dialysis from perfusate containing $0,5,20$, or $40 \mathrm{nM} \mathrm{DA}\left(D A_{\text {in }}\right)$, and the average linear regression, for each experimental group. An estimate of extracellular DA concentration is given by $D A_{\text {ext }}$ and is that concentration of $D A_{\text {in }}$ from which no DA is gained or lost during dialysis $\left(D A_{\text {in }}-D A_{\text {out }}=0\right)$. The in vivo $E_{\mathrm{d}}$, an indirect measure of DA uptake, is given in the slope of the line. Data are given by treatment group as follows: $\square=\mathrm{Veh}+\mathrm{Coc}(20 \mathrm{mg} / \mathrm{kg}$, i.p.; $n=12) ; \square=\mathrm{Veh}+\mathrm{Sal}(n=12) ; \bigcirc=\mathrm{U}-69+\operatorname{Coc}(n=13) ; \bigcirc=\mathrm{U}-69$ $(0.32 \mathrm{mg} / \mathrm{kg}$, s.c. $)+$ Sal $(n=10)$. Cocaine significantly increased $E_{\mathrm{d}}$, and U-69593 significantly decreased $E_{\mathrm{d}}(p<0.05$; main effects identified by two-way ANOVA). No significant group differences in $D A_{\text {ext }}$ were found.

Table 1. Basal extracellular DA concentration $\left(D A_{\mathrm{ext}}\right)$ and in vivo extraction fraction $\left(E_{\mathrm{d}}\right)$ in rat Acb $3 \mathrm{~d}$ after a $5 \mathrm{~d}$ treatment with cocaine with or without the selective $\kappa$-opioid receptor agonist U-69593

\begin{tabular}{lclc} 
Treatment & $D A_{\text {ext }}(\mathrm{nM})$ & $E_{\mathrm{d}}$ & $n$ \\
\hline Vehicle + saline & $10.9 \pm 2.1$ & $0.22 \pm 0.03$ & 12 \\
U-69593 + saline & $13.3 \pm 2.1$ & $0.11 \pm 0.01^{a}$ & 10 \\
Vehicle + cocaine & $11.4 \pm 1.7$ & $0.31 \pm 0.06^{b}$ & 12 \\
U-69593 + cocaine & $9.9 \pm 2.5$ & $0.18 \pm 0.03^{a, b}$ & 13
\end{tabular}

${ }^{a}$ U-69593 significantly decreased $E_{\mathrm{d}}(p<0.05$ by main effect identified by two-way ANOVA.

${ }^{b}$ Cocaine significantly increased $E_{\mathrm{d}}$ ( $p<0.05$ by main effect identified by two-way ANOVA).

\section{Effect of repeated U-69593 + cocaine on [ $\left.{ }^{125} \mathrm{I}\right] \mathrm{RTI}-55$ autoradiography in Acb and STR}

$\left[{ }^{125}\right.$ I]RTI-55 binding (femtomoles per milligram of tissue), in the presence of unlabeled $50 \mathrm{~nm}$ citalopram to prevent binding to the serotonin transporter, was used to determine the influence of repeated U-69593 treatment alone or in combination with cocaine, on DAT binding density in the $\mathrm{Acb}_{\text {shell }}, \mathrm{Acb}_{\text {core }}$, and dorsal STR. The mean ( \pm SEM) binding density is given in Table 3 and illustrated in Figure 4. No significant interactions between U-69593 treatment and cocaine treatment were found $\left(F_{(1,12)}<1\right.$ in each analysis). However, in the Acb, a significant main effect of U-69593 on $\left[{ }^{125}\right.$ I]RTI-55 binding was found in both the shell and core regions $\left(F_{(1,12)}=5.30, p=0.04\right.$ and $F_{(1,12)}=5.01, p=0.04$, respectively). In each region, repeated U-69593 treatment significantly decreased [ ${ }^{125}$ I]RTI-55 binding (33 and 35\% in the shell and core, respectively). The decrease in [ ${ }^{125}$ I]RTI-55 binding was evident in both U-69593 + saline and U-69593 + cocaine tissues (Table 3). A similar trend, although not statistically significant, was observed in the dorsal STR $\left(F_{(1,12)}=4.46, p=0.056\right)$. No differences as a result of cocaine administration were observed in any statistical analyses. 


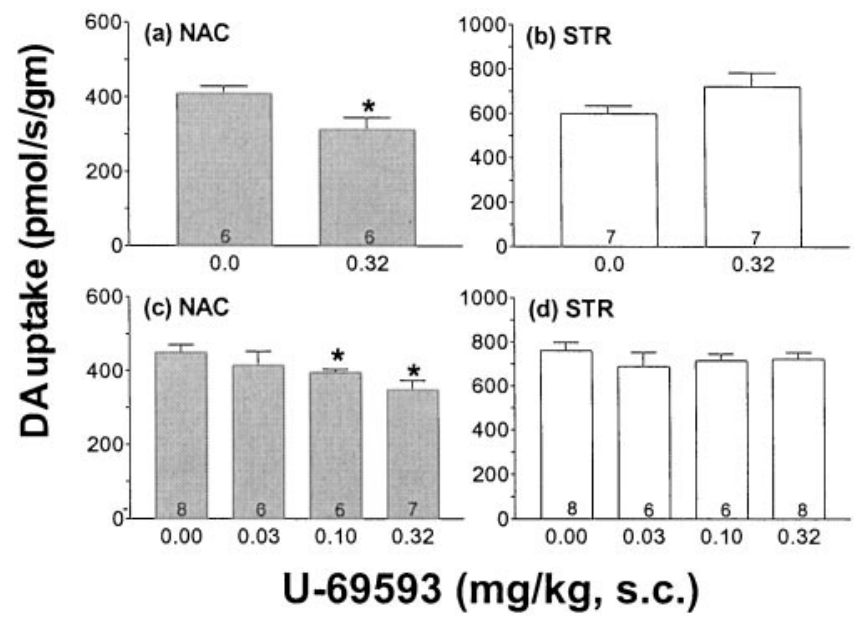

Figure 3. The effect of repeated U-69593 treatment on the initial rate of DA uptake in Acb and STR. $a, b$, DA uptake was measured in minced Acb and STR tissue by rotating disk electrode voltammetry, 3 d after a $5 \mathrm{~d}$ repeated drug treatment (U-69593, $0.32 \mathrm{mg} / \mathrm{kg}$, s.c., or vehicle, once per day,). $c, d$, The effect of various doses of repeated U-69593 on the initial rate of DA uptake into Acb and STR was assessed. DA uptake was measured in minced Acb and STR tissue by rotating disk electrode voltammetry, $3 \mathrm{~d}$ after a $5 \mathrm{~d}$ repeated drug treatment (U-69593 or vehicle, once per day), at the dose indicated on the $x$-axis. Data are presented as group means \pm SEM. The numbers at the bottom of the bar $=n . * p \leq 0.05$ versus $0 \mathrm{mg} / \mathrm{kg}$ control group by one-way ANOVA.

Table 2. Changes in the kinetic parameters of DA transport into Acb suspensions $3 \mathrm{~d}$ after a $5 \mathrm{~d}$ treatment with $\mathrm{U}-69593$

\begin{tabular}{llll} 
Treatment & $\begin{array}{l}K_{\mathrm{m}} \\
(\mu \mathrm{M})\end{array}$ & $\begin{array}{l}V_{\max } \\
(\mathrm{pmol} / \mathrm{gm} / \mathrm{sec})\end{array}$ & $n$ \\
\hline U-69593 & $1.36 \pm 0.15^{*}$ & $658 \pm 34^{*}$ & 11 \\
Vehicle & $0.99 \pm .08$ & $573 \pm 18$ & 11
\end{tabular}

${ }^{*} p<0.05$ different from controls by one-way ANOVA.

\begin{tabular}{|c|c|c|c|c|}
\hline Treatment & $\mathrm{Acb}_{\text {shell }}$ & $\mathrm{Acb}_{\text {core }}$ & Dorsal STR & $n$ \\
\hline Vehicle + saline & $18 \pm 3$ & $43 \pm 7$ & $70 \pm 6$ & 4 \\
\hline U-69593 + saline & $13 \pm 4 *$ & $31 \pm 7^{*}$ & $52 \pm 10^{* *}$ & 5 \\
\hline Vehicle + cocaine & $23 \pm 2$ & $46 \pm 1$ & $66 \pm 3$ & 4 \\
\hline U-69593 + cocaine & $14 \pm 3^{*}$ & $29 \pm 6^{*}$ & $49 \pm 8^{* *}$ & 3 \\
\hline
\end{tabular}

$* p<0.05$ different from controls by two-way ANOVA (main effect of U-69593) ** $p=0.056$ different from controls by two-way ANOVA (main effect of U-69593).

\section{Effect of repeated U-69593 + cocaine treatment on DAT concentration in the Acb and STR}

The concentration of DAT in Acb and STR tissue was assessed by immunoblot to determine whether the changes in the rate of DA uptake induced by U-69593 and cocaine, or the combination, were the result of a change in DAT protein. The results are reported in Table 4, and a representative Western Blot is illustrated in Figure 5. Relative to controls, DAT immunoreactivity was unchanged by repeated administration of U-69593 in either $\operatorname{Acb}\left(F_{(1,10)}=1.4\right.$, $p=0.27)$ or $\operatorname{STR}\left(F_{(1,10)}<1\right)$. In contrast, a significant difference was found between controls, repeated cocaine treatment, and repeated U-69593 + cocaine treatment groups in the Acb $\left(F_{(2,15)}=\right.$ $3.9, p=0.04)$. In this case, repeated coadministration of cocaine with U-69593 resulted in a significant increase in DAT immunoreactivity in Acb homogenates $(p<0.05)$. Cocaine treatment alone produced intermediate levels of DAT immunoreactivity not statisti-

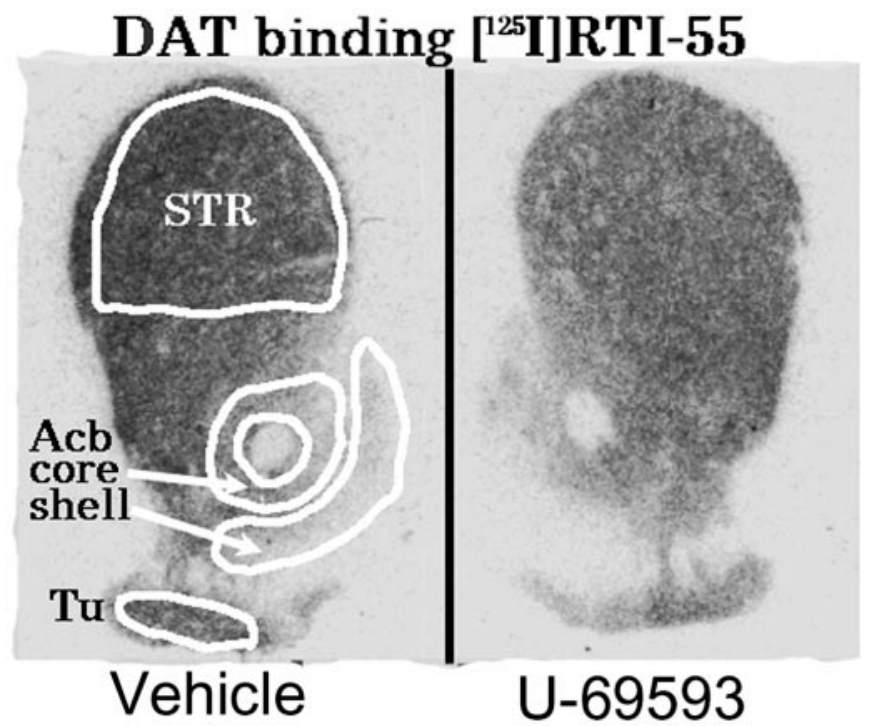

Figure 4. A modified composite of the forebrain at the levels of the STR showing how four regions were sampled for [ $\left.{ }^{125} \mathrm{I}\right] \mathrm{RTI}-55$ binding comparing control (left) and U-69593 (right) treatment. Acb core, Nucleus accumbens core subdivision; Acb shell, nucleus accumbens shell subdivision; STR, caudoputamen; Tu, olfactory tubercles. Statistical analysis on group data indicated that DAT binding was significantly reduced in U-69593 treatment rats (Table 3 ).

Table 4. DAT immunoreactivity in the Acb and dorsal STR $3 \mathrm{~d}$ after a 5 d treatment with cocaine and/or the selective $\kappa$-opioid receptor agonist U-69593

\begin{tabular}{llcl} 
Treatment & Acb & Dorsal STR & $n$ \\
\hline U-69593 & $112 \pm 11$ & $95 \pm 3$ & 6 \\
Cocaine & $132 \pm 22$ & $129 \pm 14$ & 6 \\
Vehicle + U-69593 & $186 \pm 30^{*}$ & $112 \pm 13$ & 6
\end{tabular}

$\overline{\text { Data expressed as percentage of control immunoreactivity } \pm \text { SEM. }{ }^{*} p<0.05 \text { different }}$ from controls by one-way ANOVA.

cally different from either controls or U-69593 + cocaine treatment. Similar effects were not found in the $\operatorname{STR}\left(F_{(2,15)}=1.6, p=0.23\right)$.

\section{Effect of an acute U-69593 treatment on DA uptake in $\mathbf{A c b}$}

In view of the changes in DA uptake after repeated treatment with U-69593, experiments were conducted to characterize the effect of acute U-69593 administration on DA uptake. Figure $6 a$ shows the rate of DA uptake in Acb at various time points after a single U-69593 $(0.32 \mathrm{mg} / \mathrm{kg}$, s.c.) or vehicle injection. A significant timedependent increase in the rate of DA uptake in the Acb was observed after U-69593 administration $\left(F_{(3,22)}=5.3, p=0.007\right)$. The greatest increase in uptake was apparent $2 \mathrm{hr}$ after the injection. Figure $6 b$ shows that this effect was dose-related $\left(F_{(3,27)}=4.2\right.$, $p=0.02)$.

\section{Effect of $n B N I$ on the acute action of U-69593 on DA uptake}

nBNI (10 mg/kg, s.c.), a $\kappa$-opioid receptor antagonist, was used to determine the role of $\kappa$-opioid receptors in mediating the acute effect of U-69593 on DA uptake in the Acb. A significant two-way interaction between $\mathrm{nBNI}$ treatment and U-69593 treatment was found $\left(F_{(1,19)}=6.67, p<0.02\right)$ (Fig. $\left.6 c\right)$. nBNI treatment blocked the increased rate of DA uptake induced by a single U-69593 injection. No significant effect of nBNI alone on DA uptake was observed. 


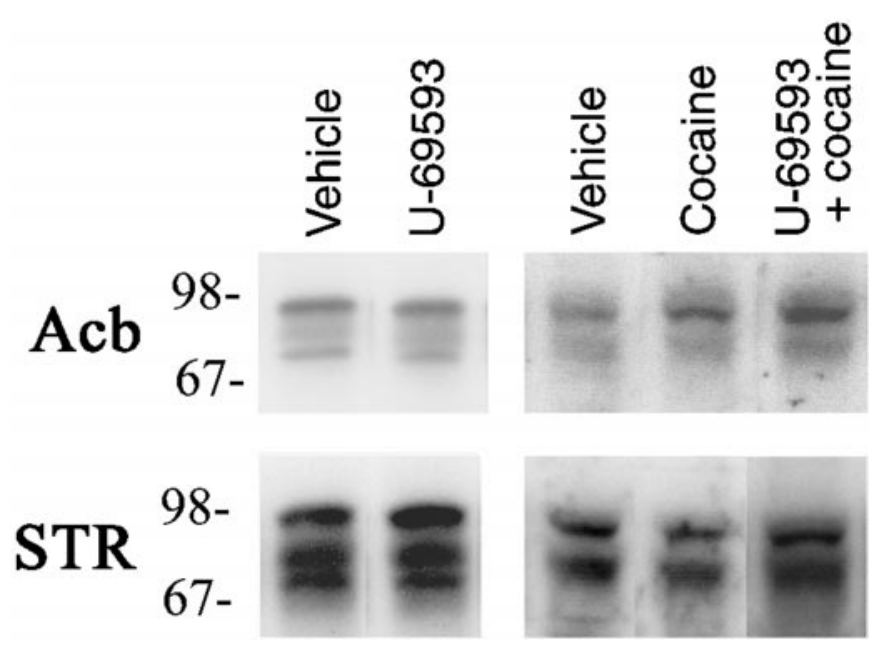

Figure 5. Western blot analysis of dopamine transporter. Representative DAT immunoreactivity in Acb or STR homogenates from rats treated with U-69593 or vehicle (left panels), and vehicle, cocaine, or cocaine + U-69593 (right panels). Tissue was collected $3 \mathrm{~d}$ after a $5 \mathrm{~d}$ repeated treatment regimen. Comparable results were obtained in two independent experiments in which tissue from three rats per treatment group was assessed in triplicate. Statistical analyses on group data revealed a significant increase in DAT immunoactivity in Acb homogenates from U-69593 + cocainetreated rats (Table 4).

\section{DISCUSSION}

\section{Repeated systemic U-69593 or cocaine treatment produces opposing adaptations in presynaptic DA activity}

The no net flux microdialysis method was used here to determine whether repeated administration of the selective $\kappa$-agonist, U-69593, with cocaine prevents the cocaine-induced changes in DA uptake and release that occur during the early phase of abstinence from cocaine. This microdialysis method provides additional information about the mechanism(s) that underlies changes in monoamine dialysate concentration that cannot be obtained by conventional dialysis methods (see Results). Marked and opposing effects of repeated U-69593 and cocaine treatment on basal DA uptake in the Acb were observed (Fig. 2). DA $E_{\mathrm{d}}$ was increased $3 \mathrm{~d}$ after the cessation of repeated cocaine administration $(20 \mathrm{mg} / \mathrm{kg}$, i.p., once per day for $5 \mathrm{~d}$ ), whereas extracellular DA levels were unchanged. This finding is in line with previous reports (Parsons et al., 1991; Kalivas et al., 1993a). Repeated U-69593 administration significantly decreased DA $E_{\mathrm{d}}$ but did not change $D A_{\text {ext }}$, suggesting that in contrast to repeated cocaine administration, repeated $\kappa$-agonist administration leads to a decrease in DA uptake and release.

In rats that had received U-69593 with cocaine, $E_{\mathrm{d}}$ was intermediate to that produced by each drug alone and approximated control levels. Statistical analysis revealed significant main effects for U-69593 and cocaine treatments and no significant interaction, suggesting that each drug alone modified DA uptake. Thus, repeated activation of $\kappa$-opioid receptors during cocaine administration may prevent cocaine-induced alterations in DA neurotransmission by producing long-term alterations in basal DA uptake and release that are opposite to those produced by cocaine.

\section{DA uptake is decreased after repeated systemic U-69593 treatment}

Direct evidence to support the conclusion that repeated U-69593 treatment decreases DA uptake was obtained using RDE voltammetry that measures DA uptake in vitro. The initial rate of DA uptake in the Acb from U-69593-treated rats was significantly lower than in vehicle-treated controls. The magnitude of the effect was dose dependent, and the effective doses (0.1 and $0.32 \mathrm{mg} / \mathrm{kg}$, i.p.) were those previously shown to block behavioral sensitization to cocaine (Heidbreder et al., 1993; Shippenberg et al., 1996). DA uptake was unaltered in STR tissue, suggesting that the effect of U-69593 administration on DA uptake is region specific (Fig. 3). The changes in uptake observed in the Acb were associated with a significant increase in $K_{\mathrm{m}}(37 \%)$ and $V_{\max }(15 \%)$ (Table 2). The change in $K_{\mathrm{m}}$ is consistent with the observed decrease in DA uptake; however, this effect is counteracted at least in part by an increase in $V_{\text {max }}$. Further analysis of the kinetic consequences of repeated $\kappa$-agonist treatment would require additional information such as the number of functional transporters.

\section{DAT binding and total DAT protein are altered after repeated systemic U-69593 treatment alone, or in combination with cocaine}

Repeated U-69593 treatment also reduced [ ${ }^{125}$ I]RTI-55 binding in the core and shell of the Acb (Fig. 4). These results provide the first demonstration that repeated U-69593 treatment downregulates DAT in the Acb and suggest that U-69593-induced decreases in DA uptake may result from a decrease in DAT activity. Preliminary studies suggest that the U-69593 treatment regimen decreases the $B_{\max }$ of [ $\left.{ }^{3} \mathrm{H}\right]$ W IN 35,428 (Izenwasser et al., 1997) or [ $\left.{ }^{125} \mathrm{I}\right] \mathrm{RTI}-$ 55 (Sharpe et al., 1999) to DAT in the Acb. These effects, however, do not appear to be mediated by loss of protein, because immunoblotting revealed no decrease in DAT immunoreactivity after U-69593 treatment. Alternatively, repeated U-69593 treatment may lead to post-translational modifications of DAT that affect

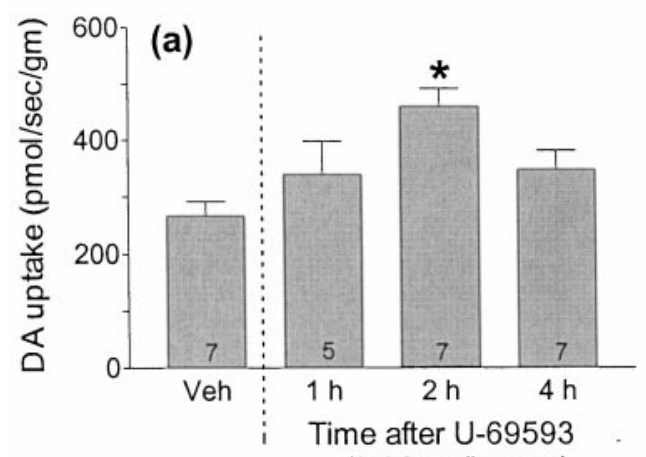

$(0.32 \mathrm{mg} / \mathrm{kg}$,s.c.)

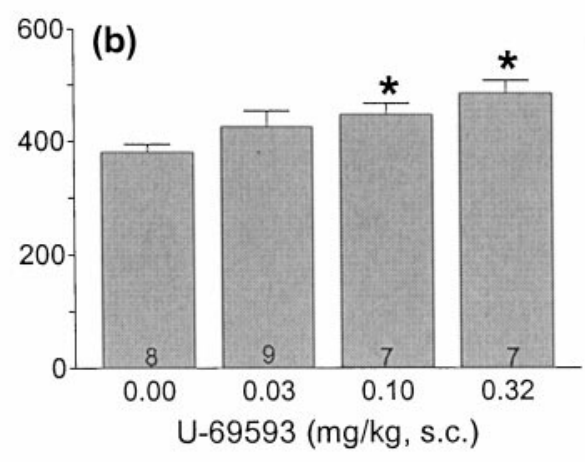

$\mathrm{U}-69593(\mathrm{mg} / \mathrm{kg}, \mathrm{s.c}$ )

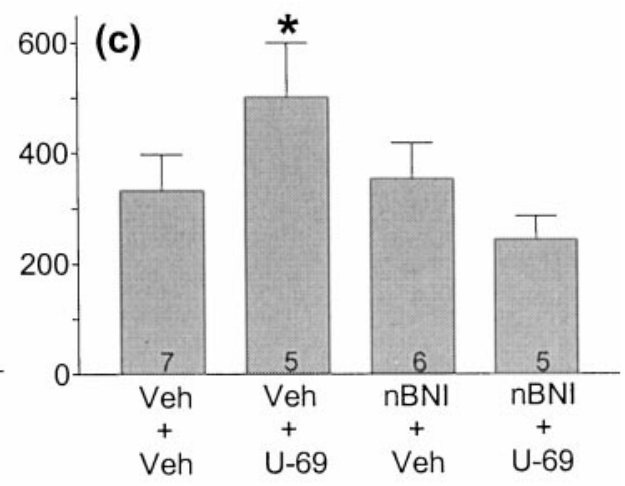

Figure 6. The acute effect of U-69593 on the initial rate of DA uptake in Acb. In $a$, DA uptake was measured in tissue minces by rotating disk electrode voltammetry 1,2 , or $4 \mathrm{hr}$ after a single U-69593 injection $(0.32 \mathrm{mg} / \mathrm{kg}$, s.c.). In $b$, DA uptake was measured in tissue minces by rotating disk electrode voltammetry $2 \mathrm{hr}$ after the various doses of U-69593 were administered. In $c$, the effect of nBNI (10 mg/kg, s.c.), a selective $\kappa$-opioid receptor antagonist, on the U-69593-induced increase in the rate of DA uptake in the Acb was assessed. nBNI was administered $24-48$ hr before the U-69593 treatment. The initial rate of DA uptake (mean \pm SEM) was determined in Acb tissue by rotating disk electrode voltammetry $2 \mathrm{hr}$ after U-69593 (0.32m/kg, s.c.) treatment. Data are presented as group means \pm SEM. $n=$ the numbers at the bottom of the bars. ${ }^{*} p<0.05$ versus control group $(a, b)$, by one-way ANOVA. ${ }^{*} p<0.05$ versus control group by two-way ANOVA $(c)$. 
antagonist binding and DA uptake. For example, repeated $\kappa$-agonist treatment is associated with an upregulation of protein kinase C (PKC) activity in brain tissue (Feng et al., 1996). Activation of PKC is known to increase DAT phosphorylation (Huff et al., 1997; Vaughan et al., 1997), promote its internalization, and decrease DA uptake (Daniels and Amara, 1999; Melikian and Buckley, 1999), consistent with the results observed on DA uptake here. Internalization of DAT may also affect its availability to bind $\left[{ }^{125}\right.$ I]RTI-55 and DA, leading to decreased DAT binding in the absence of a decrease in total DAT protein. Protein kinase $\mathrm{C}$ is also activated by acute $\kappa$-opioid receptor stimulation, as are other signaling cascades (Belcheva et al., 1998; Zhang and Wong, 1998; Bohn et al., 2000). However, whether these effects mediate the observed changes in DA uptake after acute $\kappa$-agonist treatment is unclear.

Repeated administration of cocaine increased DA uptake but produced no changes in total DAT protein or $\left[{ }^{125} \mathrm{I}\right] \mathrm{RTI}-55$ binding to DAT. This suggests that the increases in DA uptake observed during the early phase of cocaine abstinence (Parsons et al., 1991; Meiergerd et al., 1994) (see Experiment 1 here) are not caused by an upregulation in DAT. In contrast, repeated administration of cocaine in combination with U-69593 produced a significant decrease in DAT binding to [ $\left.{ }^{125} \mathrm{I}\right] \mathrm{RTI}-55$ and a significant increase in total DAT protein in the Acb (Figs. 4, 5). It is unclear how increases in DAT expression, in the face of decreased transporter binding, can account for the normalization of DA uptake observed in rats receiving repeated cocaine with U-69593. However, increasing evidence suggests that changes in DAT function (e.g., increases or decreases in DA uptake) can be dissociated from changes in protein expression and ligand recognition sites (Kitayama et al., 1992; Lee et al., 1996 ; Kokoshka et al., 1998).

\section{DA uptake is increased after the acute administration of U-69593}

The acute administration of $\kappa$-agonists decreases basal DA dialysate levels in the Acb (DiChiara and Imperato, 1988; Donzanti et al., 1992; Spanagel et al., 1992), an effect that has been attributed to a decrease in DA cell firing and DA release. The present voltammetry studies provide the first demonstration that acute $\kappa$-opioidreceptor stimulation increases DA uptake rather than, or in addition to, decreasing DA release in the Acb (Fig. $6 b$ ). The increase in DA uptake was nBNI-reversible, supporting a receptor-specific effect (Fig. $6 c$ ), and the effective dose was that which decreased DA uptake after repeated administration. The time course study revealed that the increase in DA uptake was not immediate. Maximal effects were observed $2 \mathrm{hr}$ after U-69593 injection (Fig. $6 a$ ). These findings are particularly noteworthy because $\kappa$-agonist-induced decreases in dialysate levels develop slowly over 30-60 min. Together these data suggest that acute $\kappa$-opioid receptor activation may decrease DA neurotransmission by two distinct mechanisms: an inhibition of release and a later-onset increase in DA uptake. These data also suggest that the decrease in DA uptake produced by repeated U-69593 treatment may be a compensatory response to the increase in DA uptake produced by acute $\kappa$-opioid receptor activation.

One mechanism by which $\kappa$-agonists attenuate the behavioral and neurochemical effects of cocaine may be by modifying DA uptake in the Acb. $\kappa$-agonists may block some or all of the acute effects of cocaine on DA activity by increasing the rate of DA uptake or decreasing DA release, or both (Smith et al., 1992). A similar mechanism may also underlie the ability of $\kappa$-agonists to prevent alterations in behavior and DA activity in the Acb. The present studies, however, also indicate that $\kappa$-agonists may prevent changes in behavior and DA activity that occur after cessation of repeated cocaine administration by inducing an opposing neuronal adaptation. If this were true, concurrent administration of a $\kappa$-agonist with cocaine would not be necessary to "reverse" the cocaine-induced neurochemical alterations. Indeed, previous work suggests that $\kappa$-agonist and cocaine treatment need not be coinci- dental (Shippenberg and Heidbreder, 1995; Mello and Negus, 1998).

In conclusion, the activation of $\kappa$-opioid receptors regulates DA uptake in the Acb. DA uptake is increased after acute $\kappa$-opioid receptor activation and decreased $3 \mathrm{~d}$ after repeated $\kappa$-agonist treatment. These effects oppose both the acute and long-term effects of cocaine on presynaptic DA activity in the Acb and provide a plausible mechanism by which $\kappa$-agonists prevent alterations in behavior that occur in response to the repeated administration of cocaine.

\section{REFERENCES}

Belcheva MM, Vogel Z, Ignatova E, Avidor-Reiss T, Zippel R, Levy R, Young EC, Barg J, Coscia CJ (1998) Opioid modulation of extracellular signal-regulated protein kinase activity is ras-dependent and involves $\mathrm{G}_{\beta \gamma}$ subunits. J Neurochem 70:635-645.

Bohn LM, Belcheva MM, Coscia CJ (2000) Mitogenic signaling via endogenous $\kappa$-opioid receptors in C6 glioma cells: evidence for the involvement of protein kinase $\mathrm{C}$ and the mitogen-activated protein kinase signaling cascade. J Neurochem 74:564-573.

Bungay PM, Morrison PF, Dedrick RL (1990) Steady-state theory for quantitative microdialysis of solutes and water in vivo and in vitro. Life Sci 46:105-119.

Burnette WB, Bailey D, Kukoyi S, Blakely RD, Trowbridge CG, Justice Jr JB (1996) Human norepinephrine transporter kinetics using rotating disk electrode voltammetry. Anal Chem 68:2932-2938.

Cosford RJ, Vinson AP, Kukoyi S, Justice JB Jr (1996) Quantitative microdialysis of serotonin and norepinephrine: pharmacological influences on in vivo extraction fraction. J Neurosci Methods 68:39-47.

Daniels GM, Amara SG (1999) Regulated trafficking of the human dopamine transporter. Clathrin-mediated internalization and lysosomal degradation in response to phorbol esters. J Biol Chem 274:35794-35801.

DiChiara G, Imperato A (1988) Opposite effects of mu and kappa opiate agonists on dopamine release in the nucleus accumbens and in the dorsal caudate of freely moving rats. J Pharmacol Exp Ther 244:1067-1080.

Donzanti BA, Althaus JS, Payson MM, Von Voigtlander PF (1992) Kappa agonist-induced reduction in dopamine release: site of action and tolerance. Res Commun Chem Pathol Pharmacol 78:193-210.

Feng Y, Narita M, Makimura M, Hoskins B, Ho IK (1996) Effects of repeated administration of a kappa-opioid agonist on phorbal ester binding to membrane-bound protein kinase $\mathrm{C}$ in rat brain. Biol Pharmacol Bull 19:303-304.

Heidbreder CA, Shippenberg TS (1994) U-69593 prevents cocaine sensitization by normalizing basal accumbens dopamine. NeuroReport 5:1797-1800.

Heidbreder CA, Goldberg SR, Shippenberg TS (1993) The kappa-opioid receptor agonist U-69593 attenuates cocaine-induced behavioral sensitization in the rat. Brain Res 616:335-338.

Heidbreder CA, Thompson AC, Shippenberg TS (1996) Role of extracellular dopamine in the initiation and long-term expression of behavioral sensitization to cocaine. J Pharmacol Exp Ther 278:490-502.

Henry DJ, White FJ (1995) The persistence of behavioral sensitization to cocaine parallels enhanced inhibition of nucleus accumbens neurons. J Neurosci 15:6287-6299.

Henry DJ, Greene MA, White FJ (1989) Electrophysiological effects of cocaine in the mesoaccumbens dopamine system: repeated administration. J Pharmacol Exp Ther 351:833-839.

Horan P, Taylor J, Yamamura HI, Porreca F (1992) Extremely longlasting antagonistic actions of nor-binaltorphimine (nBNI) in the mouse tail-flick test. J Pharmacol Exp Ther 260:1237-1243.

Huff RA, Vaughan RA, Kuhar MJ, Uhl GR (1997) Phorbal esters increase dopamine transporter phosphorylation and decrease transport $\mathrm{V}_{\text {max }}$ J Neurochem 68:225-232.

Izenwasser S, Thompson AC, Shippenberg TS (1997) Repeated administration of a selective kappa-opioid receptor agonist decreases dopamine transporter number in the nucleus accumbens of the rat. NIDA Res Monogr 178:275.

Jones SR, Garris PA, Wightman MR (1995) Different effects of cocaine and nomifensine on dopamine uptake in the caudate-putamen and nucleus accumbens. J Pharmacol Exp Ther 274:396-403.

Justice JB (1993) Quantitative microdialysis of neurotransmitters. J Neurosci Methods 48:263-276.

Kalivas PW, Duffy P (1993a) Time course of extracellular dopamine and behavioral sensitization to cocaine. I. Dopamine axon terminals. J Neurosci 13:266-275.

Kalivas PW, Duffy P (1993b) Time course of extracellular dopamine and behavioral sensitization to cocaine. II. Dopamine perikarya. J Neurosci 13:276-284.

Kalivas PW, Stewart J (1991) Dopamine transmission in the initiation and expression of drug- and stress-induced sensitization of motor activity. Brain Res Rev 16:223-244.

Kitayama S, Shimada S, Xu H, Markham L, Donovan DM, Uhl GR (1992) Dopamine transporter site-directed mutations differentially alter substrate transport and cocaine binding. Proc Natl Acad Sci USA 89:78-83. 
Kokoshka JM, Vaughan RA, Hanson GR, Fleckenstein AE (1998) Nature of methamphetamine-induced rapid and reversible changes in dopamine transporters. Eur J Pharmacol 351:269-275.

Kuhar MJ, Unnerstall JR (1990) Receptor autoradiography. In: Methods in neurotransmitter receptor analysis (Yamamura HI, Enna SJ, Kuhar MJ, eds), pp 177-218. New York: Raven.

Kuhar MJ, Ritz MC, Boja JW (1991) The dopamine hypothesis of the reinforcing properties of cocaine. Trends Neurosci 14:299-302.

Lahti RA, Mickelson MM, McCall JM, Von Voightlander PF (1985) $\left[{ }^{3} \mathrm{H}\right] \mathrm{U}-69593$ : a highly selective ligand for the opioid kappa receptor. Eur J Pharmacol 109:281-284.

Lee FJ, Pristupa ZB, Ciliax BJ, Levey AJ, Niznik HB (1996) The dopamine transporter carboxyl-terminal tail. Truncation/substitution mutants selectively confer high affinity dopamine uptake while attenuating recognition of the ligand binding domain. J Biol Chem 271:20885-20894.

Letchworth SR, Sexton T, Childers SR, Vrana KE, Vaughan RA, Davies HML, Porrino LJ (1999) Regulation of rat dopamine transporter mRNA and protein by chronic cocaine administration. J Neurochem 73:1982-1989.

Lett BW (1989) Repeated exposures intensify rather than diminish the rewarding effects of amphetamine, morphine, and cocaine. Psychopharmacology 98:347-362.

Lönnroth P, Jansson PA, Smith U (1987) A microdialysis method allowing characterization of intercellular water space in humans. Am J Physiol 253:E228-E231.

Lönnroth P, Jansson PA, Fredholm BB, Smith U (1989) Microdialysis of intercellular adenosine concentration in subcutaneous tissue in humans. Am J Physiol 256:E250-E255.

Maisonneuve IM, Archer S, Glick SD (1994) U50,488, a kappa opioid receptor agonist, attenuates cocaine-induced increases in extracellular dopamine in the nucleus accumbens of rats. Neurosci Lett 181:57-60.

Meiergerd SM, McElvain JS, Schenk JO (1994) Effects of cocaine and repeated cocaine followed by withdrawal: alterations of dopaminergic transporter turnover with no changes in kinetics of substrate recognition. Biochem Pharmacol 47:1627-1634.

Melikian HE, Buckley KM (1999) Membrane trafficking regulates the activity of the human dopamine transporter. J Neurosci 19:7699-7710.

Mello NK, Negus SS (1998) Effects of kappa opioid agonists on cocaineand food-maintained responding by rhesus monkeys. J Pharmacol Exp Ther 286:812-824.

Ng JP, Hubert GW, Justice Jr JB (1991) Increased stimulated release and uptake of dopamine in nucleus accumbens after repeated cocaine administration as measured by in vivo voltammetry. J Neurochem 56:1485-1492.

Parsons LH, Smith AD, Justice JB Jr (1991) Basal extracellular dopamine is decreased in the rat nucleus accumbens during abstinence from chronic cocaine. Synapse 9:60-65.

Paxinos G, Watson C (1986) The rat brain in stereotaxic coordinates, Ed 2. New York: Plenum.

Povlock SL, Schenk JO (1997) A multisubstrate kinetic mechanism of dopamine transport in the nucleus accumbens and its inhibition by cocaine. J Neurochem 69:1093-1105.
Reith ME (1988) Cocaine receptors on monoamine transporters and sodium channels. NIDA Res Monogr 88:23-43.

Ritz MC, Cone EJ, Kuhar MJ (1990) Cocaine inhibition of ligand binding at dopamine, norepinephrine and serotonin transporters: a structureactivity relationship. Life Sci 46:635-645.

Schenk JO, Patterson TA, McElvain JS (1990) Rotating disk voltametric measurements in neurobiology and neuropharmacology. Trends Anal Chem 9:325-330.

Schenk S, Partridge B (1997) Sensitization and tolerance in psychostimulant self-administration. Pharmacol Biochem Behav 57:543-550.

Sharpe LG, Rothman RB, Dersch CM, Thompson A, Shippenberg TS (1999) Kappa-opioid receptor agonist, U-69593, dowregulates the dopamine transporter in mesolimbic regions of the rat brain. Soc Neurosci Abstr 25:304.

Shippenberg TS, Heidbreder C (1995) Sensitization to the conditioned rewarding effects of cocaine: pharmacological and temporal characteristics. J Pharmacol Exp Ther 273:808-815.

Shippenberg TS, LeFevour A, Heidbreder C (1996) kappa-Opioid receptor agonists prevent sensitization to the conditioned rewarding effects of cocaine. J Pharmacol Exp Ther 276:545-554.

Smith AD, Justice JB (1994) The effect of inhibition of synthesis, release, metabolism and uptake on the microdialysis extraction fraction of dopamine. J Neurosci Methods 54:75-82.

Smith JD, Loughlin SE, Leslie FM (1992) kappa-Opioid inhibition of $\left[{ }^{3} \mathrm{H}\right]$ dopamine release from rat ventral mesencephalic dissociated cell cultures. Mol Pharmacol 42:575-583.

Spanagel R, Herz A, Shippenberg TS (1992) Opposing tonically active endogenous opioid systems modulate the mesolimbic dopaminergic pathway. Proc Natl Acad Sci USA 89:2046-2050.

Spanagel R, Almeida OF, Shippenberg TS (1994) Evidence that norbinaltorphimine can function as an antagonist at multiple opioid receptor subtypes. Eur J Pharmacol 264:157-162.

Stewart J, Badiani A (1993) Tolerance and sensitization to the behavioral effects of drugs. Behav Pharmacol 4:289-313.

Vaughan RA, Kuhar MJ (1996) Dopamine transporter ligand binding domains. J Biol Chem 271:21672-21680.

Vaughan RA, Uhl G, Kuhar MJ (1993) Recognition of dopamine transporters by antipeptide antibodies. Mol Cell Neurosci 4:209-215.

Vaughan RA, Huff RA, Uhl GR, Kuhar MJ (1997) Protein kinase $\mathrm{C}$-mediated phosphorylation and functional regulation of dopamine transporters in striatal synaptosomes. J Biol Chem 272:15541-15546.

Welch SM, Justice Jr JB (1996) Regulation of dopamine uptake in rat striatal tissue by NMDA receptors as measured using rotating disk electrode voltammetry. Neurosci Lett 217:1-5.

Wise RA, Bozarth MA (1987) A psychomotor stimulant theory of addiction. Psychol Rev 94:469-492.

Zhang W-M, Wong T-M (1998) Suppression of cAMP by phosphoinosital $/ \mathrm{Ca}^{2+}$ pathway in the cardiac $\kappa$-opioid receptor. Am J Physiol 274: C82-87. 